Pavel Janičko

\title{
Precarious work in the Czech Republic and the approach of ČMKOS
}

\begin{abstract}
This article provides information as regards the extent and usage of flexible forms of employment in the Czech labour market, as well as the extent to which 'flexibilisation' may resolve the problems of unemployment exacerbated by the growthrelated difficulties caused by the crisis. The author, an economic analyst with the Czech trade union, ČMKOS, notes that certain forms of flexible labour, such as parttime and temporary work, are less in use in the Czech Republic than they are in the rest of the EU as a whole, since the demand from employees is for full-time, openended employment opportunities. Likewise, the author dismisses any notion that the Czech labour market is a barrier to the creation of the necessary new jobs, dismissing these as a solution to the current crisis conditions, and arguing instead for policies designed to strength aggregate demand and create jobs. Finally, the article reviews recent changes to the Labour Code designed to encourage flexibility, commenting that these generally reduce protections for employees rather than improve opportunities.
\end{abstract}

Keywords: precarious work, flexicurity, supply side, crisis, unemployment, parttime, temporary work, self-employment, Švarc system, agency employment, Labour Code, illegal work, welfare protection, employment rights

Introduction

The aim of this article is to provide some information on the use and impact of precarious (or insecure, or flexible) forms of employment in the Czech Republic and also to provide some comparisons with the situation in the EU. In characterising the concept of precariousness itself and in defining its relevant specifics, we can say that "precarious" forms of employment are those which have long been promoted as a possible tool better to adapt the supply side of labour market demand, as well as addressing issues in the reconciliation of work and family life. At the same time, however, especially in the context of the ongoing economic crisis and its impact on the labour market, an open question is the extent to which the flexibility of work can have the effect of increasing the number of jobs and their quality, i.e. the extent to which this process can be considered as a truly effective tool for resolving the problems of the labour market (e.g. long-term unemployment, problems of employment for young people, people approaching retirement age, etc.).

Increasingly, the Czech Republic is standing out in Europe as regards the negative pressures of labour market flexibility, reflected particularly in social dumping and the still more onerous problem of the so-called 'working poor', the essence of which lies 
in an unacceptable reduction in labour costs (in particular via reductions in wages and reduced social security contributions), the deterioration of working conditions and the reduction of minimum labour standards and forms of labour protection.

The way to overcome these negative side effects of flexibility is seen primarily in the application of the principles of 'flexicurity', which refers to the setting of conditions that allow both objectives to be fulfilled, i.e. to gain the required degree of flexibility while maintaining internationally-established standards for work.

This overview is based mostly on the positions of the biggest Czech trade union organisation, the Czech Moravian Trade Union Confederation (ČMKOS). This results from the role of the author, who is an economic analyst for the organisation and who has taken part in many negotiations and discussions in which he has formulated the position of the trade union position and reacted to the views of his negotiating counterparts. Moreover, the author has come to the conclusion that the objective facts lead to the inescapable conclusion that pressure towards heightening so-called flexible forms of employment have not had any substantial impact regarding positive moves on labour markets.

The case of the Czech Republic can provide further arguments in this direction.

\section{Flexible forms of employment}

In opening this discussion, we must first describe properly the basic concepts. Precarious forms of employment have many forms, most often work in part-time jobs, on fixed-term contracts, in temporary employment agencies and in self-employment (entrepreneurship), largely taking shape in agreements on work performed outside employment (contract of service and contract for work). Flexible working time encompasses a variety of working time arrangements, offered as options for flexible start and end times to working hours, working time accounts, job sharing, working from home (teleworking), etc.

Flexible forms of work can be divided into the following types:

- internal working time flexibility

- various irregular working patterns

- flexible working hours (flexitime)

- flexible working hours - on daily, weekly, four-weekly cycles

- breaks from work

- short-time working (part-time work), employment concluded on the basis of shorter working hours

- overtime

- working hours accounts

- compressed work weeks (or other appropriate adjustments of working hours to re-distribute work time either evenly or unevenly)

- working hours designed to accommodate the school year

- sharing of work (job sharing, or work sharing) 
- external working time flexibility (various types of contracts and time)

- illegal forms - forms of employment contrary to the law on the basis of a licence ( švarcsystém)

- legal forms:

- temporary work

- part-time work

- $\quad$ work carried out outside an employment relationship

- working at home

- distance work (teleworking)

- transfer to another job

- sabbatical

- time-off for training (study leave to pursue qualifications or to acquire new or improve existing skills)

- phased or partial retirement.

This general outlook will be further addressed with regard to the distribution and impact in the Czech Republic of the more essential forms of flexible work and employment, mainly in the areas of part-time work, temporary work, agency employment and bogus self-employment (under the Švarc system - named after a Czech entrepreneur, J. Švarc, who was infamous in the early nineties for transforming his employees into positions of false self-employment).

\section{Precarious forms of work in the Czech Republic}

In the Czech Republic, as in other EU member countries, precarious forms of work are gradually becoming increasingly a part of everyday life. Employees, primarily for economic reasons (since Czech wages still lag far behind wages in the most advanced countries of the European Union (EU-15)), prefer to work full-time and on an openended basis, but eventually are willing to accept overtime, night shifts and weekend working.

However, employers are increasingly demanding that job seekers work part-time, on fixed-term contracts or on a temporary agency basis, or are willing to employ them only on the basis of work performed outside standard forms of employment (agreement on work activity, as if self-employed), which represents the most flexible, i.e. the most precarious, forms of employment.

The higher levels of protection in European comparison are guaranteed to employees in the Czech Republic only on the basis of work on open-ended contracts. Meanwhile, the degree of protection for temporary employment contracts is lower, and the terms of agreement for work performed outside an employment relationship is quite low, often in conflict with the minimum standards required by the conventions of the International Labour Organization.

The use of precarious forms of work in the Czech Republic in recent years has been affected by the ongoing economic crisis and the unfavourable developments in the economies of most European Union member states, including the Czech Republic. According to an analysis of trends in employment and unemployment in 2012 (con- 
ducted by MPSV $\check{C L R}^{1}$ in 2013), the overall employment rate of people aged 20-64 reached $71.5 \%$ in the Czech Republic in 2012 while the average unemployment rate was $8.6 \%$. However, we can see that total unemployment encompasses an increased proportion of unemployed young people under 25 years of age, at $18.8 \%$, as well as an increased share of the long-term unemployed (over 12 months), at $35.3 \%$.

At this point, it is useful to highlight the actual state of unemployment in general terms and, in connection with this, also briefly to illustrate the economic history of the crisis in the Czech Republic.

\section{Figure 1 - Development of real GDP and unemployment in the Czech Republic}

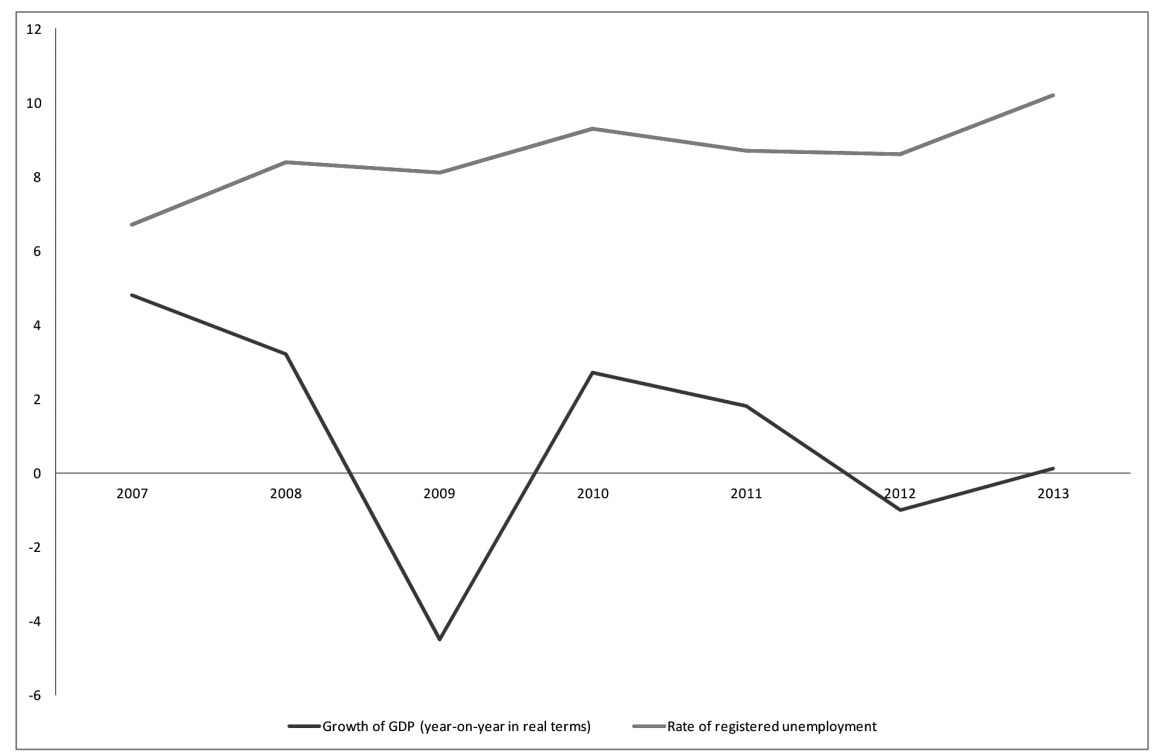

Source: MPSV and MF of the Czech Republic. Data for 2013: projection by MF ČR and the actual rate of unemployment.

This picture gives us clear information on the deteriorating economic performance partially, of course, derived from the external situation but, in a very significant way, also caused by the ineffective economic policies of the Czech government. In any case, the situation on the Czech labour market is very negative and unsatisfactory. Actually, more than 500000 people are in the position of looking for work and registered as job seekers at labour offices. In this situation, we can often hear opinions raising the topic of the flexibilisation of the labour market as a possible tool for turning employment in a positive direction.

1 MPSV ČR: Ministerstvo práce a sociálních věci - Czech Ministry of Labour and Social Affairs; MF ČR: Ministerstvo financi - Czech Ministry of Finance. 
ČMKOS, in contrast, underlines that the rate of flexibility of the labour market is definitively not a main factor standing behind the level of employment and unemployment and a more positive effect can only be brought about by a more reasonable economic and social policy oriented towards the creation of new jobs and in strengthening the aggregate demand side of the economy.

That shifts in the precariousness of the labour market have no positive impact on the resolution of the problem of unemployment could be documented by the following analysis describing changes in some types of employment in the Czech Republic, and demonstrating that negative developments in this sphere are much more a consequence and cause of unemployment than likely to make a contribution to its resolution.

\section{Types of job contracts}

The data in Tables 1 and 2 confirm that the Czech Republic is, so far, typical by its low share of non-standard (flexible, precarious) work (or forms of work). Neither has this situation been changed as a result of this period of crisis in the Czech economy and on the Czech labour market. The Czech Republic is often criticised for not giving more room to part-time jobs as a possible means to address unemployment, but it can be stated that companies resolve employment problems rather by redundancy and the transfer of staff to self-employed positions than via the use of forms of short-time working.

One reason for this is that part-time work for Czech employees is not attractive, because of the significant reduction in wages and lower labour law protection and because they do not usually ensure the possibility of switching to standard forms of employment in full-time jobs. Czech employees thus perceive non-standard forms of employment only as a temporary escape from actual crisis; engagement in these forms of employment is just a temporary, or an emergency, solution. 
Table 1 - Types of job contracts in the Czech Republic

\begin{tabular}{|l|c|c|c|c|c|c|c|c|c|c|}
\hline & \multicolumn{2}{|c|}{2008} & \multicolumn{2}{c|}{$\mathbf{2 0 0 9}$} & \multicolumn{2}{c|}{$\mathbf{2 0 1 0}$} & \multicolumn{2}{c|}{2011} & \multicolumn{2}{c|}{$\mathbf{2 0 1 2}$} \\
\cline { 2 - 10 } & $\begin{array}{c}\text { Num- } \\
\text { ber of } \\
\text { per- } \\
\text { sons } \\
\mathbf{( 0 0 0 )}\end{array}$ & $\begin{array}{c}\text { Share } \\
\text { of total } \\
\text { em- } \\
\text { ploy- } \\
\text { ment } \\
\mathbf{( \% )}\end{array}$ & $\begin{array}{c}\text { Num- } \\
\text { ber of } \\
\text { per- } \\
\text { sons } \\
\mathbf{( 0 0 0 )}\end{array}$ & $\begin{array}{c}\text { Share } \\
\text { of total } \\
\text { em- } \\
\text { ploy- } \\
\text { ment } \\
\mathbf{( \% )}\end{array}$ & $\begin{array}{c}\text { Num- } \\
\text { ber of } \\
\text { per- } \\
\text { sons } \\
\mathbf{( 0 0 0 )}\end{array}$ & $\begin{array}{c}\text { Share } \\
\text { of total } \\
\text { em- } \\
\text { ploy- } \\
\text { ment } \\
\mathbf{( \% )}\end{array}$ & $\begin{array}{c}\text { Num- } \\
\text { ber of } \\
\text { per- } \\
\text { sons } \\
\mathbf{( 0 0 0 )}\end{array}$ & $\begin{array}{c}\text { Share } \\
\text { of total } \\
\text { em- } \\
\text { ploy- } \\
\text { ment } \\
\text { (\%) }\end{array}$ & $\begin{array}{c}\text { Num- } \\
\text { ber of } \\
\text { per- } \\
\text { sons } \\
\text { (000) }\end{array}$ & $\begin{array}{c}\text { Share } \\
\text { of total } \\
\text { em- } \\
\text { ploy- } \\
\text { ment } \\
\mathbf{( \% )}\end{array}$ \\
\hline $\begin{array}{l}\text { Total em- } \\
\text { ployment }\end{array}$ & 5002.5 & 100.0 & 4934.3 & 100.0 & 4885.2 & 100.0 & 4904.0 & 100.0 & 4890.1 & 100.0 \\
\hline $\begin{array}{l}\text { Open- } \\
\text { ended job } \\
\text { contracts, } \\
\text { entrepre- } \\
\text { neurs }\end{array}$ & 4663.6 & 93.2 & 4586.0 & 92.9 & 4527.7 & 92.7 & 4560.0 & 93.0 & 4538.5 & 92.8 \\
\hline $\begin{array}{l}\text { Fixed-term } \\
\text { contracts }\end{array}$ & 337.0 & 6.7 & 347.2 & 7.0 & 356.8 & 7.3 & 342.9 & 7.0 & 351.5 & 7.2 \\
\hline $\begin{array}{l}\text { Full-time } \\
\text { contracts }\end{array}$ & 4750.0 & 95.1 & 4660.9 & 94.5 & 4596.5 & 94.1 & 4636.7 & 94.5 & 4607.4 & 94.2 \\
\hline $\begin{array}{l}\text { Part-time } \\
\text { contracts }\end{array}$ & 269.3 & 4.9 & 273.1 & 5.5 & 288.6 & 5.9 & 267.4 & 5.5 & 282.5 & 5.8 \\
\hline
\end{tabular}

Source: Materials of MPSV $\check{C} R$

Table 2 - Share of temporary employees and employees with part-time jobs

\begin{tabular}{|c|c|c|c|c|}
\hline \multirow{2}{*}{} & \multicolumn{2}{|c|}{$\begin{array}{c}\text { Temporary jobs (in \% of total } \\
\text { employment) }\end{array}$} & \multicolumn{2}{c|}{$\begin{array}{c}\text { Part-time work (in \% of total } \\
\text { employment) }\end{array}$} \\
\cline { 2 - 5 } & EU-27 & Czech Republic & EU-27 & Czech Republic \\
\hline 2007 & 14.6 & 8.6 & 18.2 & 5.0 \\
\hline 2008 & 14.2 & 8.0 & 18.2 & 4.9 \\
\hline 2009 & 13.6 & 8.5 & 18.8 & 5.5 \\
\hline 2010 & 14.0 & 8.9 & 19.2 & 5.9 \\
\hline 2011 & 14.1 & 8.5 & 19.5 & 5.5 \\
\hline
\end{tabular}

Source: Eurostat 
Table 3 - Employment by age and type of employment contract (EU-27, 2010)

\begin{tabular}{|l|c|c|c|c|}
\hline & $\begin{array}{c}\text { Up to } \\
\text { 30 years }\end{array}$ & $\mathbf{3 0 - 4 9}$ years & $\begin{array}{c}\text { Over } \\
\text { 50 years }\end{array}$ & Total \\
\hline Open-ended contracts & 61 & 86 & 87 & 81 \\
\hline Fixed-term contracts & 39 & 14 & 13 & 19 \\
\hline Total & 100 & 100 & 100 & 100 \\
\hline Part-time employment & 28 & 22 & 26 & 24 \\
\hline Full-time employment & 72 & 78 & 74 & 76 \\
\hline Total & 100 & 100 & 100 & 100 \\
\hline
\end{tabular}

Source: European Foundation (2012) Sustainable work and the ageing workforce Eurofound Working Conditions Survey, Dublin.

This data quite clearly shows that, in the European area (for the EU), there is a significant relationship between age and type of employment contract. Above all, younger age groups are more often employed on fixed-term and part-time work; consequently, they are often the subject of the process of work being made more precarious.

For a better orientation, we can also point to data showing that the Czech Republic, in comparison with the EU, is still, at least in terms of the proportion of people employed on non-standard working hours, relatively behind the EU average. 
Table 4 - Proportion of part-time contracts and fixed-term jobs in total employment (\%)

\begin{tabular}{|l|c|c|c|c|c|c|c|c|c|}
\hline & \multicolumn{3}{|c|}{$\mathbf{2 0 0 0}$} & \multicolumn{3}{c|}{$\mathbf{2 0 1 0}$} & \multicolumn{3}{c|}{2011} \\
\cline { 2 - 11 } & $\begin{array}{c}\text { Part- } \\
\text { time } \\
\text { con- } \\
\text { tracts } \\
\text { (Men) }\end{array}$ & $\begin{array}{c}\text { Part- } \\
\text { time } \\
\text { con- } \\
\text { tracts } \\
\text { Wo- } \\
\text { men }\end{array}$ & $\begin{array}{c}\text { Fixed- } \\
\text { term } \\
\text { con- } \\
\text { tracts }\end{array}$ & $\begin{array}{c}\text { Part- } \\
\text { time } \\
\text { con- } \\
\text { tracts } \\
\text { (Men) }\end{array}$ & $\begin{array}{c}\text { Part- } \\
\text { time } \\
\text { con- } \\
\text { tracts } \\
\text { Wo- } \\
\text { men }\end{array}$ & $\begin{array}{c}\text { Fixed- } \\
\text { term } \\
\text { con- } \\
\text { tracts } \\
\text { Part- } \\
\text { time } \\
\text { con- } \\
\text { tracts } \\
\text { (Men) }\end{array}$ & $\begin{array}{c}\text { Part- } \\
\text { time } \\
\text { con- } \\
\text { tracts } \\
\text { wo- } \\
\text { men }\end{array}$ & $\begin{array}{c}\text { Fixed- } \\
\text { term } \\
\text { con- } \\
\text { tracts }\end{array}$ \\
\hline Czech Republic & 1.6 & 5.4 & 9.3 & 2.3 & 7.0 & 8.9 & 1.9 & 6.6 & 8.5 \\
\hline Germany & 4.8 & 33.3 & 12.7 & 7.9 & 37.9 & 14.7 & 8.5 & 38.0 & 14.7 \\
\hline France & 5.5 & 24.9 & 15.5 & 5.7 & 22.4 & 15.0 & 5.8 & 22.1 & 15.3 \\
\hline Spain & 7.3 & 21.4 & 32.1 & 9.7 & 18.8 & 24.9 & 9.8 & 18.4 & 25.3 \\
\hline Sweden & 9.3 & 24.0 & 10.2 & 13.5 & 25.4 & 8.4 & 13.8 & 25.2 & 8.8 \\
\hline Denmark & 13.4 & 57.2 & 14.0 & 17.2 & 60.6 & 18.5 & 17.1 & 60.5 & 18.4 \\
\hline Netherlands & 1.0 & 2.9 & 4.8 & 2.8 & 5.9 & 5.8 & 2.7 & 5.7 & 6.6 \\
\hline Slovakia & 4.0 & 5.4 & 16.4 & 7.2 & 12.1 & 17.3 & 6.7 & 10.9 & 18.2 \\
\hline Slovenia & 5.8 & 20.2 & 11.3 & 9.0 & 25.3 & 11.9 & 9.1 & 26.0 & 12.0 \\
\hline OECD & & 16.1 & 4.9 & 21.7 & 24.0 & 5.5 & 21.9 & 25.3 \\
\hline
\end{tabular}

Source: OECD (2012) Employment Outlook.

Table 5 - Share of self-employed people in the economically active population (\%)

\begin{tabular}{|l|c|c|c|}
\hline & $\mathbf{2 0 0 0}$ & $\mathbf{2 0 0 5}$ & $\mathbf{2 0 1 0}$ \\
\hline Czech Republic & 15.2 & 16.1 & 17.8 \\
\hline Slovakia & 8.0 & 12.6 & 16.0 \\
\hline Poland & 27.4 & 25.8 & 22.8 \\
\hline Italy & 28.5 & 27.0 & 25.5 \\
\hline Germany & 11.0 & 12.4 & 11.6 \\
\hline Austria & 13.1 & 13.3 & 13.8 \\
\hline France & 9.3 & 9.1 & 10.1 \\
\hline Great Britain & 12.8 & 12.9 & 13.8 \\
\hline USA & 7.4 & 7.5 & 7.0 \\
\hline EU 27 & 18.3 & 17.3 & Not available \\
\hline
\end{tabular}

Source: $O E C D$ 


\section{Self-employment}

Czech Republic is, however, among the countries which have a very high proportion of people with self-employment status, as is illustrated in Table 5. The proportion of self-employed people in the Czech Republic is particularly high in comparison with countries such as Germany and Austria (and the Scandinavian countries) and is even markedly higher than in Anglo-Saxon countries (UK and the USA), with their typically high preference for 'entrepreneurship'. Furthermore, the figure is approaching the level of the countries of southern Europe (Italy, Spain and Greece), which have a slightly different structure of the economy (a large proportion of small-scale services, or in agriculture), and which are characterised by a high level of the grey economy, as documented in the following table:

Table 6 - Share of the 'grey' economy in GDP (2012, \%)

\begin{tabular}{|l|c|}
\hline Austria & 7.6 \\
\hline Netherlands & 9.5 \\
\hline Great Britain & 10.1 \\
\hline France & 10.8 \\
\hline Germany & 16.3 \\
\hline Sweden & 14.3 \\
\hline Slovakia & 15.3 \\
\hline Czech Republic & 16.0 \\
\hline EU & 18.4 \\
\hline Spain & 19.2 \\
\hline Italy & 23.6 \\
\hline Greece & 24.0 \\
\hline Romania & 29.1 \\
\hline Bulgaria & 31.9 \\
\hline
\end{tabular}

Source: $M P S V \check{C} R$

The interpretation of this phenomenon consists in the structure of economic shifts in the transition countries of eastern Europe (the decrease in the number of large enterprises and an increasing share taken by services), further reducing the protection afforded to standard employment relationships; but also undoubtedly the growth of illegal employment practices - in this context in the Czech Republic, especially the boom in the 'Švarc system'.

Very characteristic is that rates of self-employment are in some way proportional to the level of unemployment; high rates of unemployment are, in most cases, typical 
of countries that are characterised by a higher proportion of illegal work and also a higher proportion of self-employed people.

\section{Agency employment}

An important factor that can create significant problems is employment undertaken through employment agencies. The reason is that agency work is a place in which illegal practices occur highly frequently while it also encourages the adoption of social dumping mechanisms on the Czech labour market.

This type of employment has been adapted from the changes made in the 2004 Employment Act. In 2011, some legislative changes were introduced that tightened authorisation procedures as regards recruitment. It also introduced compulsory insurance agencies, which should increase legal certainty for temporary agency workers. The result of these changes is that the number of agencies operating in the Czech market has decreased.

Table 7 - Number of agencies and agency-assigned employment in the Czech Republic

\begin{tabular}{|c|c|c|}
\hline Year & $\begin{array}{c}\text { Total number of agency-registered } \\
\text { workers assigned to employers }\end{array}$ & $\begin{array}{c}\text { Number of employment } \\
\text { agencies }\end{array}$ \\
\hline 2004 & 7202 & 690 \\
\hline 2005 & 56192 & 1474 \\
\hline 2006 & 50122 & 1810 \\
\hline 2007 & 6427 & 2228 \\
\hline 2008 & 230455 & 2214 \\
\hline 2009 & 164507 & 1714 \\
\hline 2010 & 195586 & 1453 \\
\hline 2011 & 172069 & 1483 \\
\hline 2012 & 197144 & 1484 \\
\hline Until & & \\
\hline 30 March 2013 & & \\
\hline
\end{tabular}

Source: MPSV ČR Analýzy vývoje zaměstnanosti a nezaměstnanosti.

When calculating the total number of the economically active population, the share of agency workers in the Czech Republic stands at $0.7 \%$ while the EU average is at $1.5 \%$. The average length of the assignment of agency employees to client employers is one month ( $27 \%$ of workers), one to three months $(38 \%)$ and over three months (35\%). Temporary employment is also often associated only with manual labour but this type of employment is, however, used to employ workers at all levels. The MPSV survey shows that the number of agencies and the number of people they assigned to 
clients escalated in 2008 and that, in the following years, and due to the economic crisis, this decreased by tens of thousands.

An important role in these developments was also played by the adoption during the last year of legislation tightening agency work.

Some changes in the Labour Code on the path to the flexibilisation of the Czech labour market

In this context, we can note some changes and amendments to labour legislation documents over the last two years which have sought to modify and adjust labour market conditions as regards their flexibility characteristics. Nevertheless, it is necessary to take into account that the most important measures on the path to the flexibilisation of the labour market in the Czech Republic had been taken in previous years, particularly at the beginning of the so-called transition in the early nineties, when the obligation to negotiate with trade unions any job or reduction of workers was removed; a step which opened up the space for much more easy dismissals. At the same time, the possibility of the wider use of forms of self-employment was applied and the distinctions between standard and non-standard jobs thus became both more frequent and more unclear.

The second pro-flexible moment came after the Czech Republic joined the EU when, among the new European norms, the institution of job agencies was accepted.

Let us remind ourselves of the main changes to the Labour Code which have been realised in the last two years, with the new Code being in force since 1 January 2012.

\section{Changes to the rules (duration, chaining) in respect of employment relationships concluded for a definite period of time}

The period of time over which it is possible repeatedly to extend an employment relationship concluded for a fixed period of time has increased from two to three years. This means that it is easier to agree this type of employment relationship and thereby further impede standard employment relationships concluded on an open-ended basis, or otherwise make them more disadvantageous.

Changes to the amount of statutory severance pay (now according to the number of years employed)

The amount of severance pay upon the termination of employment for organisational reasons is now dependent on the duration of employment in the employer in question prior to the dismissal. This in practice means a decrease in severance pay for younger employees.

Prolongation of the period of equalisation in connection with the flexible scheduling of working hours and new rules for crediting overtime to the working hours account

In this connection, ČMKOS supported this step, which allows greater flexibility in scheduling employees' working hours in cases where the company has to respond to a sudden increase in orders. This practice allows companies to avoid sudden lay-offs of employees. 
Increasing the number of hours worked based on an agreement to complete ajob (from 150 to 300)

This measure, conversely, was severely criticised by ČMKOS, as it again gives employers a substantial amount of room to abuse precarious forms of employment.

\section{Summary}

In general, ČMKOS believes that the changes being prepared to the Labour Code, despite partial improvements in the legal regulation of labour law relationships, generally roll back the protections and certainties enjoyed by employees and infringe their union rights. The proposed amendments still leave too much space for precarious forms of employment relationships (that do not provide employees with the same protections) and set up the conditions and legal instruments that will make it even harder for an even greater number of employees to attain open-ended full-time employment relationships - such employment being the basic condition for the development of personal, and especially family, life as well as for the achievement of a satisfactory standard of living for employees and their families.

Another change has also been included in the Employment Act where, with effect from 1 January 2013, a clarification of the definition of illegal work has been in place. This is now defined as the illegal performance of work taking place outside an employment relationship, or the use of foreign labour (from third countries) who do not have work permits. The penalties both for companies employing foreigners and also for illegal employees themselves have also been increased (up to ten million CZK and up to $50000 \mathrm{CZK}$, respectively). The law has also facilitated access by the control authorities (the Labour Inspectorate).

In this case, the position of $\breve{C} M K O S$ was supportive.

\section{Conclusions}

The employment of people is a problem that, in recent years, has become the subject of marked interest in the Czech Republic. Consequently, many opinions trying to establish ways of tackling it have appeared. The government's policy in the area of unemployment generally prefers an approach which is based on the idea that unemployment is, more or less, a result of there being too much 'comfort' in the form of the social security available to unemployed people who are thereby 'not motivated' to find jobs and not interested in taking jobs offered to them. Such an ideological approach by the government corresponds to the way it proposes to 'resolve' this problem, in which its suggestions for changes to the legislation take the direction of reducing the rights of employees and the unemployed and weakening the levels of social protection afforded to these groups. Conversely, an active employment policy, from the financial and organisational point of view, continues to be more and more disregarded while fewer and fewer resources are being expended on retraining programmes and other forms of active employment policy.

One part of this attitude is also the frequently-propagated view that the allegedly high rigidity, or low flexibility, of the labour market in the Czech Republic is one of the important barriers standing in the way of a rising number of new jobs. This opinion, 
when confronted with the reality in the Czech Republic, cannot be fully regarded as relevant. On the other hand, it is evident that the Czech reality regarding the use of flexible or precarious forms of employment is somewhat, in some parameters, different in comparison to the usual EU circumstances.

We can formulate several points that characterise the issue of precarious work in the Czech Republic:

- forms of precarious work in the Czech Republic are represented more through some specific examples like working people being accorded bogus self-employed status

- the Czech labour market does not show such a major occurrence of some precarious forms typical of other EU countries, including part-time and fixed-term types of job contracts

- the reasons for this can be found particularly in those negative aspects that cause a low interest of people in demanding this form of job as providing low income and low levels of legal protection.

\section{References}

ČMKOS Analýzy zaměstnanosti a situace na trhu práce ČMKOS 2006-2012 ( ČMKOS Analysis of Employment and the Situation on the Labour Market for 2006-2011), Prague.

European Foundation (2012) Sustainable work and the ageing workforce Eurofound Working Conditions Survey, Dublin.

Government of the Czech Republic Czech National Reform Plan for 2011 and 2012, Prague.

Ministry of Labour and Social Affairs Analýzy vývoje zaměstnanosti a nezaměstnanosti $v$ letech 2006-2012 (Analysis of the Development of Employment and Unemployment in 2006-2011), Prague.

OECD Employment Outlook 2012. 